\title{
The Role of Vocational Education and Training in the Integration of Refugees in Austria, Denmark and Germany
}

\author{
Christian Helms Jørgensen ${ }^{1}$, Hannes Hautz ${ }^{\star 2}$, Junmin Li $^{3}$ \\ ${ }^{1}$ Roskilde University, Department of People and Technology, Universitetsvej 1, \\ 4000 Roskilde, Denmark \\ ${ }^{2}$ Johannes Kepler University Linz, Linz School of Education, Department of Educational \\ Research, Altenberger Straße 69, 4040 Linz, Austria \\ ${ }^{3}$ University of Cologne, Chair of Economics and Business Education, Herbert-Lewin-Str. 2, \\ 50931 Cologne, Germany
}

Received: 26 January 2021, Accepted: 28 June 2021

\begin{abstract}
Context: Vocational education and training (VET) plays a crucial role in the social inclusion of refugees. The aim of this paper is to examine how the VET systems of Austria, Denmark and Germany responded to the arrival of young refugees since 2015. VET in these countries is categorised as system of collective skill formation, which offers apprenticeships in addition to school-based training. The article examines and juxtaposes the legal rights, the actual opportunities and the barriers to refugees' participation in and completion of VET at upper secondary level in the three selected countries.

Methods: The study is based on reviews of literature and an analysis of refugee policies in the three countries. The literature search used a snowballing strategy and included policy documents, research publications and grey literature from organisations of civil society. The literature review employed a narrative, issue-focused approach to explore and compare key categories relating to the research question. To elaborate, refine and structure the categories
\end{abstract}

*Corresponding author: hannes.hautz@jku.at 
for each of the three countries we used an input-process-output model and a combination of deductive and inductive analysis procedure.

Findings: The findings of the study are divided into six categories that structure the analysis: Admission requirements, validation of prior learning, vocational guidance and preparation, language training, social support measures and access to apprenticeships. The analysis reveals that both asylum seekers and recognised refugees have more opportunities in Germany than in the other two countries regarding the key categories. The findings show no major differences in the position of the social partners in the three countries in relation to refugees' participation in VET, however the national governments reacted differently to the influx of refugees. In Austria and Denmark, governments with strong anti-immigration agendas took office and reduced the access to and participation in VET for asylum seekers and refugees. At the same time, the German government introduced various integration measures for refugees in cooperation with employers with the aim of making VET more accessible to refugees.

Conclusion: To access and complete VET, refugees depend on supporting measures to overcome a variety of barriers, e.g. regarding language training and access to apprenticeships. Overall, reforms in Germany demonstrate promising initiatives to overcome the barriers to the integration of refugees in VET, while reforms in Austria and Denmark have limited refugees' opportunities to access and complete VET.

Keywords: Refugees, Social Inclusion, Vocational Education and Training, VET, VET System, Apprenticeship, Full-Time VET Schooling

\section{Introduction}

Between 2015 and 2018, more than 3.9 million asylum applications were registered in the European Union (Eurostat, 2019a). Refugees have a high risk of becoming unemployed or joining the expanding class of legal and illegal immigrants in low-wage and low-skilled jobs, thereby contributing to the dualisation of the labour market (Heidenreich, 2016). In many European countries, vocational education and training (VET $)^{1}$ is assigned a key role in integrating immigrants and refugees into education and employment (Jeon, 2019). A strong and attractive VET system is key to decreasing social inequalities and offsetting the growing dualisation of labour markets (Busemeyer, 2014). VET is crucial for the social inclusion, education and employment of young people from disadvantaged families who do not opt for higher education (Preston \& Green, 2008). This is particularly the case for refugees, who

1 When we use the term VET in this article, we refer to both initial and continuing vocational education and training. 
have often left behind their families, friends and social networks and have uncertain future prospects in the host country. VET provides specific skills that are relevant for the labour market and offers an effective and viable pathway to employment. The large majority of refugees have not completed any formal education beyond basic schooling (Winther et al., 2018), but they often have practical work experience that may be recognised in VET. In addition, during work-based learning in VET, refugees can enter the labour market and achieve a selfdetermined life in the host country.

Prior research, however, has indicated that migrants and refugees are disadvantaged in the education systems in Europe (Hillmert, 2013; Preston \& Green, 2008). Studies show that migrants have lower achievement and higher dropout rates at the upper-secondary level and are at a higher risk of not being in employment, education or training (Dicks et al., 2018; Eurostat, 2019b). This is particularly the case in the VET sector (Beicht \& Walden, 2019a). Refugees face considerable barriers and are underrepresented in VET due to language problems, employers' reserved attitudes (Phillimore \& Goodson, 2006), discrimination and integration policy (Chadderton \& Edmonds, 2015). In addition, low participation rates of migrants in VET programmes also result from self-selection mechanisms and "ethnic choice effects" (Tjaden \& Scharenberg, 2017, p. 309). Due to their parents' high educational expectations and aspirations, many migrants decide in favour of academic tracks and against VET at upper secondary level (e.g., Busse, 2020; Jackson et al., 2012; Lessard-Phillips et al., 2014). This can be partly explained by immigrant optimism and information deficits with regard to the education system of the host country (e.g., Becker \& Gretsch, 2016; Hunkler \& Tjaden, 2018). Therefore, social support, vocational guidance and pre-vocational preparation are seen as important measures to ensure refugees' access to VET (Jeon, 2019).

The so-called "refugee crisis" of 2015 became a highly contested issue on national policy agendas. Strong anti-immigration forces questioned the previous humanistic position of established political parties. Schemes for the integration, education and training of refugees were opposed by demands for exclusion and repatriation. The outcome of these political upheavals affected opportunities to organise effective VET measures for integrating refugees. This makes it relevant to ask if the VET systems in the receiving countries are able to include refugees and support their social integration and transition to the labour market.

The aim of this study is to examine the legal rights, actual opportunities and barriers to refugees' participation in and completion of initial vocational education and training (IVET) in three European countries: Austria, Denmark and Germany. The three VET systems are all categorised as systems of collective skill formation, in which businesses and labour market organisations, in collaboration with the state, play an important role in the governance of VET (Busemeyer \& Trampusch, 2012). Austria and Germany were among the European countries that received the most asylum applicants per capita (above 2\%) for 2014-2018, while Denmark received less than half (0.84\%) for the same period (Eurostat, 2019a). This 
paper describes and juxtaposes (as described in Bereday, 1964) how the IVET systems of these three countries responded to the arrival of high numbers of asylum seekers in 2015 and the subsequent years, and it contributes to the discussion about the political economy (Busemeyer \& Trampusch, 2012) of VET. So far, there is a lack of cross-European research on young refugees' access and barriers to IVET. Previous studies of refugees in VET have focused on either individual countries (e.g., Beicht \& Walden, 2019a; Rabl \& Hautz, 2018), adult learners and continuing VET (e.g., Chadderton \& Edmonds, 2015) or specific learning settings (Choy \& Wärwik, 2019). Thus, Webb et al. (2016) emphasised the need to examine VET policy differences regarding the integration of refugees and explore "how best to develop lifelong learning education to support increased mobility" and "social and economic integration" (p. 214). Our study addresses this need by examining the following research question: What are the central similarities and differences in access to and completion of IVET for refugees in Austria, Denmark and Germany?

First, the paper describes the structure of the three IVET systems under investigation as well as the position in VET of people with migration backgrounds in each country. We then present the study's research design and the criteria for juxtaposing refugees' opportunities and barriers in Austria, Denmark and Germany. Next, we explore the legal rights of refugees to participate in IVET in each of the three countries. At the heart of the paper, we outline the national refugee policy processes from 2015 to now along with the actual opportunities and barriers that refugees encounter in each national VET system. The conclusion discusses the capacities of the three national VET systems to include refugees and explores explanations for the differences identified.

\section{VET in the Three Countries}

In addition to school-based programmes, VET in all three countries offers apprenticeships (dual systems), where most of the training time (around 75\%) is work-based. The apprenticing companies and the employer organisations are strongly involved in organising the training in close cooperation with the state. The close links between the education system and labour market are associated with low youth unemployment rates and a fast transition to employment after completion of the programmes (Preston \& Green, 2008). The apprenticeship systems centre on practical and action-based forms of learning, and hereby, refugees can acquire vocational skills even if they have limited mastery of the native language. As part of their learning in the workplace, refugees can practise and develop language skills in realworld settings and extend their social networks.

While the three VET systems have many similarities, they also exhibit differences. In Austria, VET programmes attract a larger share (70\%) of all students in upper-secondary education than in Germany (48\%) and in Denmark (42\%) (Cedefop, 2018, p. 61). While 
more students in Austria attend school-based VET programmes, the large majority of VET students in the two other countries are in apprenticeships. In all three countries, apprentices attend part-time vocational schools for $20-30 \%$ of their apprenticeship time to acquire theoretical knowledge to supplement the company-based training.

The Austrian IVET system differs from the other two systems in its unique combination of dual apprenticeship training and full-time schooling (Graf et al., 2012). Apprenticeships and VET schools allow for different qualifications in similar vocational fields for young people at the upper-secondary level (e.g., Hautz \& Thoma, 2021). Thus, VET in Austria provides a greater variety of opportunities and pathways than VET in Germany and Denmark. Despite this variety, it is traditionally difficult for non-EU immigrants to participate in education and the labour market in Austria (Huddleston et al., 2015). Studies (e.g., Aschauer \& Seymer, 2019) have indicated that people with a migration background are strongly disadvantaged in the Austrian VET system. In particular, migrants from non-EU countries are underrepresented in the dual system and in full-time VET schools (Bichl, 2017). They mainly attend schools with a lower qualification level, for example, those with one- to two-year courses that prepare for social care or hospitality occupations (Herzog-Punzenberger \& Schnell, 2012). Moreover, the risk of dropping out of education and training is seven times higher for this group compared to non-migrants (Steiner, 2009).

In Denmark, apprenticeships are preceded by a preparatory year of school-based training (a basic course) for basic vocational skills. In the second year, the students shift to an apprenticeship in a company that alternates with short periods of school-based training. Ethnic minorities have higher dropout rates and face a variety of difficulties in the Danish IVET programmes, especially in accessing apprenticeships. However, in some fields with labour shortages, the situation is more favourable, and in VET for social and health care, ethnic minorities make up 25\% of the students (Danmarks Statistik, 2020). In addition to the IVET system, Denmark has an extensive public system for continuing vocational training (CVET) called AMU (Labour Market Training) (Andersen \& Kruse, 2016). For immigrants and refugees, this system offers a variety of special targeted programmes with integrated language training.

The German VET system is renowned for its strong dual system of apprenticeship, which is highly valued in the labour market. In some sectors, such as the health and childcare sectors, VET is based on full-time school-based training (Hippach-Schneider \& Huismann, 2019). In Germany in 2016, 29\% of young people between $15-25$ years of age had a migration background (Federal Statistical Office, 2018). The German VET system differs from the other two countries in the important role of vocational preparation, especially for disadvantaged groups. The so-called transition sector includes young people who have already left general education and want to prepare for a vocational training. There they learn vocational-specific skills and at the same time they can obtain a higher school certificate. This system has a high 
proportion of young people with a migration background (Seeber et al., 2019), because they have greater difficulty obtaining an apprenticeship and are less likely to be trained in their desired occupation (Beicht \& Walden, 2019b; Hupka-Brunner \& Kriesi, 2013). In contrast, people with migration background are more often overqualified for their training place and are more likely to be offered training places in occupations that have a higher rate of contract termination (Bundestinstitut für Berufsbildung, 2014).

\section{Research Design}

VET in all three countries is categorised as system of collective skill formation (Busemeyer \& Trampusch, 2012; Pilz, 2018). By comparing similar systems in the three different countries, we can get a broad picture of how this type of VET system has responded to the arrival of refugees, who represent a new group of potential students. We used a case-based approach for comparison by examining each VET system as a whole in the national context (following Bartlett \& Vavrus, 2017).

First, we conducted a literature review with a narrative, issue-focused approach to search a wide range of criteria and provide a dynamic review (as set out by Ferrari, 2015). This approach is particularly useful for comparative research because different terms in different languages can be taken into account. Through a snowballing strategy, this extensive literature review expanded to include policy documents, legal acts and research publications. It also included grey literature, for example, project reports, websites from non-governmental organisations (NGOs) and documentation of local refugee integration measures to gain insights from the practitioner perspectives.

Second, we structured the findings of the literature review using an input-process-output model (Adams, 1993) to allow better comparability between the findings for each of the three countries. During this process, the capability approach (Nussbaum \& Sen, 1993) was used to filter out the relevant categories for the research question. To ensure that we also included relevant unofficial publications prepared by civil society organisations and NGOs, we conducted a total of 16 interviews with experts and professionals in vocational schools and organisations. This gave access to a variety of empirical reports on barriers and success factors for refugees in VET, including vocational preparation and guidance, language training measures, job training and mentoring schemes.

Third, content analysis (Mayring, 2014) was used for the document analysis. We carried out the categorisation based on a combination of deductive and inductive procedures. Central categories were determined during the literature review and were subsequently modified and supplemented by categories inductively derived from the material. The findings of the document analysis were divided into six categories: Admission requirements, validation of prior learning, vocational guidance and preparation, language training, social support mea- 
sures and access to apprenticeships. To ensure the reliability of the analysis, the results of the research from the individual countries were compared, discussed and agreed upon in a reflective examination of the material within the framework of an "analyst triangulation" (as described in Patton, 1990, p. 468).

\section{$4 \quad$ Legal Rights for Refugees in VET}

Refugees who are recognised, receive a residence permit and are guaranteed the right to education by international treaties ratified by the three countries. While it is clear that compulsory education must be freely available for all children, the treaties are less clear about the rights of asylum seekers to attend upper-secondary and higher education (Willems \& Vernimmen, 2018). In this section, we examine the legal rights of refugees to VET at the upper-secondary level in the three countries.

Generally, asylum seekers are in a weak legal position concerning education and training, though they have more opportunities in Germany than in the other two countries. In Austria and Denmark, asylum seekers are excluded from apprenticeships. In Austria, access to IVET for young asylum seekers is partially legally permitted, as they are only allowed to attend full-time VET schools. During the asylum process, they are solely eligible for social welfare at a fundamental level (Asylkoordination Österreich, n.d.), and they receive no funding for transport or school supplies beyond compulsory education. Moreover, in Austria, only Syrian asylum-seekers "with high probability of being granted a residence permit" (Arbeitsmarktservice, 2021) are admitted to state-run integration courses that include vocational preparation measures. In Denmark, asylum seekers must participate in a basic introduction course 10 hours every week in the asylum centres. They can only participate in unpaid internships, not in regular VET programmes. In Germany, asylum seekers with expected residence permission already have access to integration courses during the asylum procedure. After the first three months of their stay, asylum seekers can attend pre-vocational training measures (Bergseng et al., 2019), and their opportunities for in-company training have improved with the Integration Act of 31 July 2016. If asylum seekers start an apprenticeship, they can have their residence permit extended until the end of their training period (Granato \& Junggeburth, 2017).

If asylum seekers are recognised and receive a residence permit, they acquire most of the same formal rights to education and training as native citizens in all three countries. In Austria, they are entitled to social benefits and have free access to the labour market and, thus, to all apprenticeships. For integration into the education system, the labour market and social life in Austria, recognised refugees are obliged to participate in the "integration year" (Arbeitsmarktservice, 2021), which includes language courses, pre-vocational training measures and introductory courses to Austrian culture and history. In Denmark, recognised 
refugees must participate in a standard integration programme, and since 2016, they have been required to start language and job training almost immediately. Refugees must cooperate with the municipality on a plan to become financially self-supporting. The methods vary considerably between the municipalities (Danmarks Evalueringsinstitut, 2019), but they are aimed mostly at acquiring employment within one year and only seldom at education in the regular VET system. A smaller group of refugees attend short training courses in the CVET system (AMU) that prepare them for un- and semi-skilled employment, or they attend the special two-year apprenticeship programme for refugees (IGU), which also serves as preparation for regular apprenticeships.

In Germany, both asylum seekers and recognised refugees can receive the same support from the Employment Agency as German nationals in terms of counselling, placement, support, activation and vocational integration (Der Paritätische Gesamtverband, 2017). They can take part in apprenticeship training, but they must acquire a work permit from the immigration authorities. At best, this will contain a concrete written confirmation of employment or a declaration of intent by the training company. For both asylum seekers and recognised refugees, part-time vocational training and the adjustment of the training period are possible as a way to enable the refugees' acquisition of professional and language skills. This manifests itself in an extension of the training period or in a reduction of regular in-company training time to promote language skills (Prakopchyk, 2017).

\section{$5 \quad$ National Refugee Policy: Tensions Between Integrative and Exclusionary Strategies}

In response to the arrival of a large number of refugees in 2015, the governments in all three countries launched various new initiatives to support integration through VET. However, at the same time, Austria and Denmark in particular introduced various anti-immigration measures that inhibited the participation of refugees in VET.

In Austria, following a decree in 2013, asylum seekers up to the age of 25 could get a work permit for apprenticeship training in understaffed professions. However, since 2015, the situation for asylum seekers has been very volatile due to political interventions. The Austrian government, NGOs and civil society have launched several new initiatives to support integration into and through VET. A nationwide initiative to enhance refugees' access to VET included the introduction of pre-vocational "transition classes" in 2015 (Bundesministerium für Bildung und Forschung, 2016). In these classes, refugees between the ages of 15 and 19 who were no longer of compulsory school age were prepared for upper-secondary education. However, this opportunity was abandoned in 2018 as part of the government's tightening of refugee policy. Since 2016, the Austrian government has established a large number of antiimmigration measures to create "one of the toughest asylum laws in Europe" (Brickner \& 
Krutzler, 2016). This included temporary asylum (limited to three years) and restrictions of rights to welfare and family reunion. Moreover, the government implemented stricter access to VET for refugees. The opportunity to get a work permit for apprenticeships was ended in 2018, and even repatriations for apprentices took place until the end of 2019 (Asylkoordination Österreich, n.d.). While a new act in late 2019 has enabled asylum seekers to finish their apprenticeships also in cases of negative asylum decisions, no new apprenticeships can be started by asylum seekers in Austria. In contrast with countries like Germany, asylum seekers in Austria do not get any legal security or residence status during education and training. For recognised refugees with a permanent or temporary residence permit, the situation is better. They retain the legal right to take up apprenticeships in all sectors. Their opportunities in VET are mainly negotiated between the two chambers in Austria (i.e., the Chamber of Labour and the Chamber of Commerce) and are less dependent on the political climate. However, their real opportunities for participation in VET are impeded by a variety of barriers (Rabl \& Hautz, 2018), as we will describe later.

In Denmark, the response of the new government in 2015 to the arrival of many refugees was to introduce numerous reforms with two aims (Bredgaard \& Ravn, 2018). One aim was to discourage refugees from seeking asylum in Denmark through tough anti-immigration measures, for example, significantly cutting their financial allowances. The other aim was to promote refugees' fast integration into the labour market. This marked a significant shift in integration policy from the previous priority of human capital investment in education and language training. Following tripartite negotiations with labour market partners, various new initiatives were taken to organise supported employment, job-training initiatives and new measures in VET. An innovation among these was the two-year Basic Integration Programme for refugees, IGU, introduced in 2016 by the government in cooperation with labour market organisations (Bredgaard \& Ravn, 2018). The IGU is a successful apprenticeship programme with certification that combines language training, work-based training and fulltime school-based VET courses. However, these measures apply only to recognised refugees, as asylum seekers are not allowed to take part in paid work or regular education. With a reform in 2017, completing an education no longer improves refugees' chances of acquiring a permanent residence permit. This is meant to give refugees more incentive to seek employment even though education has been shown to improve the long-term employability of refugees (Arendt, 2018). In addition, the integration allowance for refugees was reduced significantly to encourage them to find a job. A major reform of the integration policy in early 2019 emphasised that, generally, asylum is only temporary, and the policy's overall aim changed from integration to repatriation of refugees. This has made the future more uncertain for refugees and made it less useful to engage in education with a long-term perspective. It has also reduced the inclination of employers to take on refugees in apprenticeships, which typically have a duration of three years (Bredgaard \& Ravn, 2018). 
In 2016, Germany passed a new Integration Act after receiving more than one million asylum seekers. The act included measures and incentives to promote the participation of refugees in training, language courses and active labour market measures. Access to VET was previously not allowed for asylum seekers, as they did not have the required work permits (Schroeder \& Seukwa, 2017). This was changed in 2015. Starting in January of that year, the German government reformed Asylum Package I. The reforms focused primarily on asylum and residence law but also on new regulations, such as the revision of the Law on the Right of Residence (Wissenschaftliche Dienste des Bundestags, 2016). A further change was that toleration must be granted if an asylum seeker begins or has already begun qualified training, and employment bans were lifted. In addition, since then, a residence permit is granted for the total duration of the apprenticeship, as stipulated in the training contract. Asylum seekers whose asylum applications are rejected during training have the opportunity to receive a "training tolerance period" to complete their training. In such cases, however, an individual case examination by the Foreign Department is required (Deutscher Industrie- und Handelskammertag, 2017, p. 13). After completion of vocational training, a residence permit is issued for two years for the purpose of gaining employment that corresponds to the vocational qualification acquired. This legal innovation is known as the " $3+2$ regulation" (Deutscher Industrie- und Handelskammertag, 2017, p. 28) and is intended to give asylum seekers and employers more planning security, thus promoting integration through training. However, tolerated persons from "safe countries of origin" (Deutscher Industrie- und Handelskammertag, 2017, p. 28) who applied for asylum after 31 August 2015 are not entitled to this regulation. In Germany, many different measures have been launched to support refugees' participation in VET. For example, the programme Berufsorientierung für Flüchtlinge (Vocational Orientation for Refugees) (Bundesministerium für Bildung und Forschung, 2020) prepares refugees for vocational training by teaching technical language and specialist skills and providing individual mentor support. Another initiative called Companies Integrate Refugees is considered Germany's largest association in this field. The content includes knowhow on legal issues, funding opportunities, tips on cooperation and integration of refugees into training and employment.

In all three countries, the so-called "refugee crisis" of 2015 placed VET in a field of political tension, where the governments launched numerous initiatives with two partly conflicting objectives. One was to make it less attractive to seek asylum in the country, for example, by introducing temporary asylums, limiting access to education and lowering the financial benefits and living conditions of refugees. The other was to support the social integration of refugees and, in Germany, even of asylum seekers by introducing new programmes and supporting measures in VET. 


\section{Comparison of Actual Opportunities and Barriers for Refugees in VET}

Our examination has shown that asylum seekers have almost no formal rights to participate in the regular VET programmes in Austria and Denmark. For recognised refugees, the situation is different. Generally, they largely have the same formal legal opportunities to participate in VET as native citizens, though some rights might differ depending on their asylum status (temporary, permanent or Geneva protection). In the period of 2015-2020, the three countries had favourable conditions for successful integration of refugees into the labour market through VET because they had low unemployment rates and even shortages of labour in some industries (e.g., hospitality, agriculture, cleaning, etc.).

However, our study of the three countries has found considerable barriers to refugees' access to and completion of VET. The barriers are similar to those identified for immigrants (Bergseng et al., 2019; Jeon, 2019). Some barriers are related to the refugees' prior experiences, which can include trauma caused by persecution in their homeland, their subsequent flight and living under precarious and insecure conditions for extended periods. After arrival in a European country, they might experience resettlement and acculturation stress due to family separation, discrimination and the insecure situation of protracted periods waiting for asylum (Bauböck \& Tripkovic, 2017). Refugees are confronted with language and cultural barriers, and the government's emphasis on temporary asylum in Austria and Denmark raises uncertainty about the future (Baranik et al., 2018). This can lead to disappointment and demotivation and make it difficult for refugees to start VET and take control of their lives in their new environment. In addition, our examination revealed various VET-specific opportunities and barriers for refugees, which are described in more detail in the following. Table 1 illustrates an overview of the most important differences between the three countries regarding VET-specific opportunities and barriers. 
Table 1: Overview of Opportunities and Barriers in VET for Refugees

\begin{tabular}{|c|c|c|c|}
\hline & Austria & Denmark & Germany \\
\hline $\begin{array}{l}\text { Admission } \\
\text { requirements }\end{array}$ & $\begin{array}{l}\text { Successful graduation certificate } \\
\text { for the 8th school year for access } \\
\text { to full-time school-based VET. } \\
\text { Completion of compulsory } \\
\text { education, but no school } \\
\text { graduation certificate, for access } \\
\text { to the dual system. }\end{array}$ & $\begin{array}{l}\text { Successful graduation certificate } \\
\text { for the 9th grade with leaving } \\
\text { exam (Grade } 2 \text { or higher) in } \\
\text { maths and Danish (Level G) or } \\
\text { similar qualifications acquired } \\
\text { in another way. }\end{array}$ & $\begin{array}{l}\text { Successful graduation certificate } \\
\text { for the 9th grade for access to } \\
\text { full-time school-based VET. } \\
\text { Different school-based training } \\
\text { programmes require different } \\
\text { school-leaving qualification, } \\
\text { details vary across the federal } \\
\text { states. Completion of compulso- } \\
\text { ry schooling, but no successful } \\
\text { graduation certificate for access } \\
\text { to the dual system. }\end{array}$ \\
\hline $\begin{array}{l}\text { Validation of } \\
\text { prior learning }\end{array}$ & $\begin{array}{l}\text { Not a standard part of regular } \\
\text { IVET programmes. }\end{array}$ & $\begin{array}{l}\text { Basic screening of qualifications } \\
\text { by asylum centres; validation in } \\
\text { the regular IVET programmes, } \\
\text { but not a standard in the CVET } \\
\text { system. }\end{array}$ & $\begin{array}{l}\text { Not a standard part of regular } \\
\text { IVET programmes; validation } \\
\text { process varies across the federal } \\
\text { states. }\end{array}$ \\
\hline $\begin{array}{l}\text { Vocational } \\
\text { guidance and } \\
\text { pre-vocational } \\
\text { preparation }\end{array}$ & $\begin{array}{l}\text { Offered for recognised refugees } \\
\text { and Syrian asylum seekers with } \\
\text { expected residence permission } \\
\text { during the integration year. } \\
\text { Transition classes for refugees } \\
\text { were abolished by the } \\
\text { government in } 2018 \text {. }\end{array}$ & $\begin{array}{l}\text { Vocational guidance is not a } \\
\text { standard, but can be part of the } \\
\text { regular integration programme } \\
\text { for refugees. The IGU } \\
\text { programme can serve as pre- } \\
\text { vocational preparation. }\end{array}$ & $\begin{array}{l}\text { Preparatory vocational courses } \\
\text { are available in certain IVET } \\
\text { schools for school-age refugees. } \\
\text { Companies can apply for } \\
\text { funding for preparatory courses } \\
\text { for non-school-age refugees. }\end{array}$ \\
\hline $\begin{array}{l}\text { Language } \\
\text { training }\end{array}$ & $\begin{array}{l}\text { Limited offers for asylum } \\
\text { seekers; mandatory for recog- } \\
\text { nised refugees, but only offered } \\
\text { up to language level A2 by the } \\
\text { state. }\end{array}$ & $\begin{array}{l}\text { Language training is an integral } \\
\text { part of special apprenticeships } \\
\text { for refugees and of some } \\
\text { programmes in the CVET } \\
\text { system. }\end{array}$ & $\begin{array}{l}\text { Mandatory for all refugees, but } \\
\text { there is a lack of teachers and } \\
\text { poor standards for language } \\
\text { training providers. }\end{array}$ \\
\hline $\begin{array}{l}\text { Social } \\
\text { support }\end{array}$ & $\begin{array}{l}\text { No nationwide support system; } \\
\text { depends on volunteers and } \\
\text { NGOs. }\end{array}$ & $\begin{array}{l}\text { No nationwide support system; } \\
\text { differs among municipalities. }\end{array}$ & $\begin{array}{l}\text { Various support measures are } \\
\text { provided for different stages of } \\
\text { IVET. }\end{array}$ \\
\hline $\begin{array}{l}\text { Access to } \\
\text { apprenticeships }\end{array}$ & $\begin{array}{l}\text { Possible only for recognised } \\
\text { refugees; access limited due to } \\
\text { lack of support measures and } \\
\text { language skills. }\end{array}$ & $\begin{array}{l}\text { Possible only for recognised } \\
\text { refugees; access is limited due } \\
\text { to lack of language skills and } \\
\text { support measures. }\end{array}$ & $\begin{array}{l}\text { Possible for all refugees; } \\
\text { Welcome Guides support } \\
\text { companies in searching for and } \\
\text { integrating refugees. }\end{array}$ \\
\hline
\end{tabular}

\subsection{Admission Requirements for VET}

Due to language problems and incomplete basic education, it can be very difficult for refugees to meet the entrance requirements in VET. In Denmark and Austria, inadequate language skills make VET almost inaccessible for refugees, since language training for asylum seekers beyond compulsory education is only available to a limited extent during the asylum procedure. Moreover, access to full-time VET in Austria requires a successful school graduation certificate for the eighth school year, which many refugees are unable to prove. For access to the dual system in Austria, the completion of nine years of compulsory education is required, although school graduation is not. Apprenticeship companies determine further admission requirements based on their own criteria. In Denmark, asylum seekers must participate in 10 
hours of weekly training in the Danish language and introduction to Danish society. However, the level of language training is much below the entrance requirements for IVET. In 1997-2017, after receiving a residence permit, it took, on average, around five years before young refugees would start IVET (Nielsen-Gravholt \& Jans, 2020). After the new restrictions of 2016, early compulsory job training (work first policy) weakened refugees' opportunities to acquire Danish language skills (Arendt \& Bolvig, 2020). In addition, the VET reform in 2015 raised the entrance requirements (see Table 1) and reduced refugees' opportunities for accessing IVET.

In Germany, refugees are required to have completed the compulsory schooling years, but no graduation certificate is required before starting an apprenticeship. Companies select apprentices according to their own recruitment criteria (Granato \& Ulrich, 2013). Some companies do not recruit refugees due to their perceived poor German language skills and lack of expertise (Werner, 2018). To participate in full-time school-based qualifying training programmes, a certain level of language proficiency and completion of lower-secondary education is required. A specific school-leaving qualification is a prerequisite for certain types of full-time school-based training programmes. The exact requirement varies depending on the federal state.

\subsection{Validation and Recognition of Prior Learning}

Many refugees are unable to document their work experiences, and therefore, practice-based forms of validation of their prior learning are required. The validation of prior learning is regulated by law in all three countries and is a standard part of regular vocational programmes in Denmark, but not in Germany and Austria, where validation is done at the refugee's request. Validation is not used systematically in the Danish CVET system (AMU), which is most often used by refugees. Danish asylum centres must screen the refugees' qualifications but are not required to ensure proper validation (Thomassen, 2019). In Austria, a study by Eggenhofer-Rehart et al. (2018) showed that refugees' educational certificates are largely devalued by authorities and are assigned to lower levels of domestic education. In addition, some qualifications in Germany can only be validated to a limited extent due to, for example, different training systems (Winther et al., 2018).

\subsection{Vocational Guidance and Preparation (Pre-Vocational Programmes)}

Refugees have difficulties navigating the education system and need vocational guidance and preparation to make informed choices and reduce the risk of dropping out. In all three countries, preparatory vocational courses for refugees are part of the integration programmes. In Austria, vocational preparation and guidance are offered as part of the integration year 
for recognised refugees and Syrian asylum-seekers with expected residence permission who have completed compulsory schooling (Arbeitsmarktservice, 2021). This pre-vocational programme lasts 6-12 months and includes career orientation, application training, training for vocational qualifications, language skills and on-the-job training (Arbeitsmarktservice, 2021). Asylum seekers who are not from Syria, however, have only scarce offers from NGOs, as they are not available throughout Austria. In Denmark, only limited vocational guidance for refugees is included as part of the standard integration plan for the three- to six-week introduction courses and the following repeated internships in companies, which are typically 13 weeks (Bolvig \& Arendt, 2018). In addition, the two-year apprenticeship programme for refugees (IGU) can serve as preparation for the regular VET system. In Germany, preparatory vocational courses for refugees are available in some vocational schools for school-aged refugees. Companies and other IVET providers can apply for funding for preparatory courses for non-school-age refugees. The focus is on combining language support with vocational orientation and support in finding a profession and initiating a training relationship (Bundesamt für Migration und Flüchtlinge, 2017a). A basic course (PerJuF) lasts between 12 and 32 weeks. In all three countries, female refugees have far lower participation rates in VET than males, and targeted guidance measures are required to support their participation (Liebig \& Tronstad, 2018).

\subsection{Language Training Before and During VET}

To keep up with the training, refugees typically need supplementary language training before and during a VET programme. In Austria, language courses are only offered to a very limited extent during the asylum process. Depending on the federal province, only one to four hours of language training per week are offered free of charge by state institutions, and only a small number of asylum seekers are reached by these measures, as transportation is not provided (SOS Mitmensch, 2017). In 2017, language courses were made mandatory for recognised refugees. These are usually only offered to language level A2 and, therefore, provide limited support for starting and completing a VET programme. Some vocational schools and NGOs offer advanced language training for refugees, which is provided freely by teachers and volunteers. The offer of more advanced German courses varies constantly, depending on funding. The Danish IVET system is almost inaccessible to refugees due to language requirements and the restrictive integration policy. In the Danish CVET system, Danish language training is an integral part of various special courses for immigrants and refugees. In the two-year apprenticeship programmes for refugees (IGU), the Danish language is taught in close connection with vocational training, which has shown very good results (Rambøll, 2018). In Germany, the government responded to the increase in refugees by introducing numerous language support measures through integration courses (Bundesamt für Migration und Flüchtlinge, 
2017b). Participation in these courses has been mandatory for refugees since 2016. However, if the person has already begun vocational or other training in Germany or can prove participation in a comparable training programme, there is no obligation to attend an integration course. In view of this rapid development in demand for language courses, the providers of language courses have often been unable to find the necessary suitable teachers for all the courses offered. The quality of the language courses suffers from the lack of teachers and the poor standards of the providers (Kaufmann, 2016).

\subsection{Social Support Measures During VET Training}

To start a VET programme and successfully complete it, refugees require continuous social support that covers all spheres of life. In Austria and Denmark, the social support offered for refugees during VET differs considerably among municipalities and educational institutions (see e.g., Asylkoordination Österreich, n.d.; Bolvig \& Arendt, 2018). In the first years after the 2015 influx of refugees, many municipalities established support teams to help refugees manage their challenges. In both countries, some municipalities engaged integration guides and mentors to support refugees and cooperate with vocational schools and employers. Danish municipalities have an undivided responsibility for the integration process, which promotes a holistic support (Thomassen, 2019). However, many of the Danish initiatives were abandoned after 2016, when the number of refugees arriving dropped sharply. In Austria, the continued existence of most initiatives depends on the efforts of volunteers and NGOs (Rabl \& Hautz, 2018). A comprehensive nationwide support system, which would help refugees replace a missing social and family environment, does not exist in either of these two countries. In Germany, there are various measures to help companies integrate refugees. These include the external support measure assistance during training $\mathrm{A}(\mathrm{AbH}) . \mathrm{AbH}$ organises support classes and socio-pedagogical assistance for training refugees. $\mathrm{AbH}$ also offers support to stabilise the training relationship and provides support for young refugees. However, a study by the German Economic Institute (Werner, 2018) showed that many companies are not aware of these support measures and only inform themselves when concrete problems arise. Companies that know about the support measures employ significantly more refugees.

\subsection{Access to Apprenticeships and In-Company Training}

Compared to other students, refugees and immigrants have fewer chances of obtaining an apprenticeship contract. Many apprenticeships are distributed via informal social networks, and some employers are cautious about taking on ethnic minorities due to assumed cultural and language barriers (Phillimore \& Goodson, 2006). Therefore, refugees are in a disadvantaged position compared to native students in all three countries. Nevertheless, in Austria, 
apprenticeship for recognised refugees is the most promising option for successful participation in VET (Hosner et al., 2017). In most cases, however, access to dual training in Austria is only successful if refugees are given intensive support by social workers and volunteers in finding and applying for an apprenticeship, in bureaucratic matters and in finding accommodations (SOS Mitmensch, 2017). In the regular Danish IVET system, ethnic minorities are overrepresented in the full-time school-based programmes. However, many vocational schools and municipalities cooperate with employers to engage refugees in the special apprenticeship programme for refugees (IGU) aiming at industries with labour shortage (Rambøll, 2018).

In Germany, refugees have a greater chance of finding a training place in companies with a shortage of skilled workers. Welcome Guides support these companies throughout Germany in the integration of refugees. They arrange contact with refugees and advise companies that offer internships, training positions or employment opportunities for refugees. In addition, they inform companies about offers of assistance and support (Kompetenzzentrum Fachkräftesicherung, 2020). Despite the various support measures for the integration of refugees in Germany, the prior experience of companies seems to play the most important role in access to apprenticeships for refugees. This is because companies that employ staff with a migration background and already have experience with refugees are often involved in this process (Werner, 2018).

\section{Conclusion}

Asylum seekers arriving in Austria, Denmark and Germany came in a period of low unemployment and high demand for skilled workers in many industries. In all three countries, labour market organisations generally supported measures to give refugees access to VET to meet the demand for labour and to reduce the risk that refugees would add to the growing precarious class of unskilled immigrants. As these organisations have a strong position in VET, this could give VET a key role in the integration process. In all three countries, recognised refugees have the right to participate in school-based vocational education and apprenticeships on equal footing with native students. However, our study found that in Austria and Denmark, the actual opportunities for recognised refugees to enter the regular IVET system are very limited and that asylum seekers have no right to participate in the dual VET system. In Austria and Denmark, reforms in response to the so-called "refugee crisis" have reduced both groups' access to VET. This is due to new forms of temporary asylum, high admission requirements and the work first policy. The response in Germany was to expand both asylum seekers' and recognised refugees' access to VET, for example, by granting residence permits for the total training period and two additional years of employment. In addition, extended part-time vocational training in Germany supports refugees' combined acquisition of 
language and vocational skills. This is also possible in the special apprenticeship programme for refugees (IGU) in Denmark, which was introduced parallel to the restrictive reforms.

How can we explain the differences between the three countries, whose VET systems have many similarities regarding structure and governance? We have found no substantial differences in the position of the social partners in the three countries in relation to refugees, but the governments have reacted differently. In Austria (from 2016) and Denmark (from 2015), new governments took over with a strong anti-immigration agenda. In these two countries, an exclusionary political response became dominant, and the governments' negative position on immigration and refugees took precedence over their interest in upskilling refugees and immigrants in VET to meet the demands of the labour market. In contrast, the German government introduced new integrative measures in cooperation with employers to improve VET opportunities for refugees and asylum seekers.

All three countries have strong apprenticeship systems that are recognised and admired internationally for providing easy pathways to employment for disadvantaged youth (Preston \& Green, 2008). However, our study has found that this does not include refugees because they, similar to immigrants, lack social networks that provide access to apprenticeships and are subject to discriminatory practices by some employers (Jeon, 2019). In addition, the shift in Austria and Denmark to granting only temporary asylum gives refugees and employers few incentives to enter into apprenticeships that have a duration of three to four years. A variety of initiatives in Germany, such as the Welcome Guides and the Danish apprenticeship programme for refugees (IGU), are successful examples of measures to combat these disadvantages.

Our study shows that, to access and complete VET, refugees depend on supporting measures to overcome a variety of barriers in all domains of life. This is especially the case for women, who have very low participation rates in education and employment in all three countries. We have highlighted some key barriers and some promising initiatives to overcome them in the three countries. It must be expected that refugees will continue to be a challenge for Europe due to armed conflicts, climate change and global inequalities. Therefore, it is important to learn from the recent events in order to improve the general integration policy and the specific measures for refugees in VET for the next "refugee crisis". This study is mainly based on document studies in three countries. Further research is needed to explore the experiences of VET in other countries and to include the voices of the refugees themselves more directly. 


\section{References}

Adams, D. (1993). Introduction. In D. Adams (Eds.), Defining educational quality. Improving educational quality project (pp. 3-24). University of Pittsburgh.

Andersen, O. D., \& Kruse, K. (2016). Vocational education and training in Europe - Denmark. Cedefop ReferNet VET in Europe reports. https:/www.kp.dk/wp-content/uploads/2020/02/vocationaleducation-and-training-in-europe-denmark.pdf

Arbeitsmarktservice. (2021, April). The integration year.

Arendt, J. N. (2018). Sammenhongen mellem beskaftigelse og uddannelse for ikke-vestlige flygtninge og familiesammenforte [The link between employment and education for non-western refugees and family members]. Rockwool Fondens Forskningsenhed. https://www.rockwoolfonden.dk/app/ uploads/2018/06/Arbejdspapir-54-Sammenhængen-mellem-beskæftigelse-og-uddannelse.pdf

Arendt, J. N., \& Bolvig, I. (2020). Early labor market entry, language acquisition and labor market success of refugees. VIVE. https://www.vive.dk/media/pure/15357/4639057

Aschauer, W., \& Seymer, A. (2019). Zur sozialen Lage der Zugewanderten. Eine differenzierte Analyse der Bildungs- und Arbeitsmarktchancen [On the social situation of immigrants. A differentiated analysis of educational and labor market opportunities]. In W. Aschauer, M. Beham-Rabanser, O. Bodi-Fernandez, M. Haller \& J. Muckenhuber (Eds.), Die Lebenssituation von Migrantinnen und Migranten in Österreich. Ergebnisse einer Umfrage unter Zugewanderten [The Living situation of immigrants in Austria. Results of a survey among immigrants] (pp. 23-58). Springer VS.

Asylkoordination Österreich. (n.d.). Arbeitsmarktzugang [Labor market access]. http://www.asyl.at/ de/themen/arbeitsmarktzugang/

Baranik, L. E., Hurst, C. S., \& Eby, L. T. (2018). The stigma of being a refugee: A mixed-method study of refugees' experiences of vocational stress. Journal of Vocational Behavior, 105, 116-130. https:// doi.org/10.1016/j.jvb.2017.09.006

Bartlett, L., \& Vavrus, F. (2017). Comparative case studies: An innovative approach. Nordic Journal of Comparative and International Education (NJCIE), 1(1), 5-17. https://doi.org/10.7577/njcie.1929

Bauböck, R., \& Tripkovic, M. (Eds.). (2017). The integration of migrants and refugees. An EUI forum on migration, citizenship and demography. European University Institute. https://doi. org/10.2870/30835

Becker, B., \& Gretsch, C. (2016). Bildungsaspirationen in Familien mit Migrationshintergrund [Educational aspirations in families with a migration background]. In C. Diehl, C. Hunkler \& C. Kristen (Eds.), Ethnische Ungleichheiten im Bildungsverlauf: Mechanismen, Befunde, Debatten [Ethnic inequalities in educational trajectories: Mechanisms, findings, debates] (pp. 73-115). Springer VS. https://doi.org/10.1007/978-3-658-04322-3

Beicht, U., \& Walden, G. (2019a). Who dares win? Do higher realistic occupational aspirations improve the chances of migrants for access to dual vocational education and training in Germany? Journal of Education and Work, 32(2), 115-134. https://doi.org/10.1080/13639080.2019.1617840

Beicht, U., \& Walden, G. (2019b). Transition to company-based vocational training in Germany by young people from a migrant background - The influence of region of origin and generation status. International Journal for Research in Vocational Education and Training, 6(1), 20-45. https:// doi.org/10.13152/IJRVET.6.1.2

Bereday, G. (1964). Comparative method in education. Holt, Rinehart \& Winston. 
Bergseng, B., Degler, E., \& Lüthi, S. (2019). Unlocking the potential of migrants in Germany. OECD Reviews of Vocational Education and Training. OECD Publishing. https://doi.org/10.1787/82ccc2a3-en

Bichl, N. (2017). Die aktuelle österreichische Anerkennungslandschaft [The current Austrian recognition landscape]. In M. Hammerer, E. Kanelutti-Chilas, G. Krötzl \& I. Melter (Eds.), Zukunftsfeld Bildungs- und Berufsberatung IV. Schwierige Zeiten - Positionierungen und Perspektiven [Future field of educational and vocational guidance IV. Difficult times - Positioning and perspectives] (pp. 91-98). Bertelsmann. https://doi.org/10.3278/6004558w

Bolvig, I., \& Arendt, J. N. (2018). Nationale rammer for integrationsindsatsen for flygtninge 1997-2017 [National framework for integration measures for refugees 1997-2017]. VIVE. https://www.vive. $\mathrm{dk} / \mathrm{media} /$ pure/10808/2302567

Bredgaard, T., \& Ravn, T. L. (2018). Integration of refugees on the Danish labor market. Nordic Journal of Working Life Studies, 18(S4), 7-26. https://doi.org/10.18291/njwls.v8iS4.111161

Brickner, I., \& Krutzler, D. (2016, January 16). Ministerrat beschließt eines der schärfsten Asylgesetze Europas [Council of Ministers adopts one of Europe's toughest asylum laws]. Der Standard. https://www.derstandard.at/story/2000029831069/ministerrat-beschliesst-eines-der-schaerfstenasylgesetze-europas

Bundesamt für Migration und Flüchtlinge. (2017a, October). KompAS Kompetenzfeststellung, frühzeitige Aktivierung und Spracherwerb [KompAS Competence assessment, early activation and language acquisition]. Anlage zum Trägerrundschreiben 10/2017. https://www.bamf.de/SharedDocs/ Anlagen/DE/Integration/Integrationskurse/Kurstraeger/Traegerrundschreiben/2017/traegerrundschreiben-10_20170626-anlage-01.pdf?_blob=publicationFile\&v=5

Bundesamt für Migration und Flüchtlinge. (2017b, April). Bericht zur Integrationskursgeschäftsstatistik für das Jahr 2016 [Report on integration course business statistics for the year 2016]. https://www. bamf.de/SharedDocs/Anlagen/DE/Statistik/Integrationskurszahlen/Bundesweit/2016-integrationskursgeschaeftsstatistik-gesamt_bund.pdf?_blob=publicationFile\&v=2

Bundesinstitut für Berufsbildung. (2014). Datenreport zum Berufsbildungsbericht 2014: Informationen und Analysen zur Entwicklung der beruflichen Bildung [Data report on the vocational education and training report 2014: Information and analyses on the development of vocational education and training]. Bundesinstitut für Berufsbildung. https://www.bibb.de/dokumente/pdf/BIBB_Datenreport_2014.pdf

Bundesministerium für Bildung und Forschung. (2016, February). Übergangsstufe für Flüchtlinge [Transitional stage for refugees]. Schule Mehrsprachig. http://www.schule-mehrsprachig.at/index. php?id=365

Bundesministerium für Bildung und Forschung. (2020). KAUSA: Jungen Flüchtlingen Chancen bieten [KAUSA: Offering young refugees opportunities].

Busemeyer, M. R. (2014). Skills and inequality: Partisan politics and the political economy of education reforms in western welfare states. Cambridge University Press. https://doi.org/10.1017/ CBO9781107477650

Busemeyer, M. R., \& Trampusch, C. (2012). The political economy of collective skill formation. Oxford University Press. https://doi.org/10.1093/acprof:oso/9780199599431.001.0001

Busse, R. (2020). Übergangsverläufe am Ende der Sekundarstufe I. Erklärungsansätze für soziale und migrationsbezogene Ungleichheiten [Transition pathways at the end of lower secondary education. Explanatory approaches for social and migration-related inequalities]. Wbv. https://doi. org/10.3278/6004818w 
Cedefop. (2018). The changing nature and role of vocational education and training in Europe responses. Publications Office of the European Union. https://doi.org/10.2801/548024

Chadderton, C., \& Edmonds, C. (2015). Refugees and access to vocational education and training across Europe: A case of protection of white privilege? Journal of Vocational Education \& Training, 67(2), 136-152. https://doi.org/10.1080/13636820.2014.922114

Choy, S., \& Wärvik, G.-B. (2019). Integration of learning for refugee and migrant students: VET teachers' practices through practice theory lens. Journal of Vocational Education \& Training, 71(1), 87-107. https://doi.org/10.1080/13636820.2018.1518921

Danmarks Evalueringsinstitut. (2019). Store kommunale forskelle i opkvalificeringen af flygtninge [Large municipal differences in the upskilling of refugees]. https://www.eva.dk/sites/eva/files/2019-11/ Notat\%20-\%20Store\%20kommunale\%20forskelle\%20i\%20opkvalificeringen\%20af\%20flygtninge_211119_Tilgængeliggjort.pdf

Danmarks Statistik. (2020). Statistikbanken [Statistical database]. https://www.statistikbanken.dk/

Der Paritätische Gesamtverband. (2017). Handreichung - Der Zugang zur Berufsausbildung und zu den Leistungen der Ausbildungsförderung für junge Flüchtlinge und junge Neuzugewanderte [Handbook - Access to vocational education and training and support services for young refugees and young new immigrants].

Dicks, A., Dronkers, J., \& Levels, M. (2018). Cross-nationally comparative research on racial and ethnic skill disparities: Questions, findings, and pitfalls. In P. A. J. Stevens \& A. G. Dworkin (Eds.), The Palgrave handbook of race and ethnic inequalities in education (pp. 1183-1215). Palgrave Macmillan. https://doi.org/10.1007/978-3-319-94724-2_27

Deutscher Industrie- und Handelskammertag. (2017). Integration von Flüchtlingen in Ausbildung und Beschäftigung: Leitfaden für Unternehmen [Integration of refugees in training and employment: Guideline for companies]. https://www.dihk.de/resource/blob/2410/629fa385fa9be8a73698cfe93 020117f/integration-von-fluechtlingen-in-der-ausbildung-leitfaden-fuer-unternehmen-data.pdf

Eggenhofer-Rehart, P. M., Latzke, M., Pernkopf, K., Zellhofer, D., Mayrhofer, W., \& Steyrer, J. (2018). Refugees' career capital welcome? Afghan and Syrian refugee job seekers in Austria. Journal of Vocational Behavior, 105, 31-45. https://doi.org/10.1016/j.jvb.2018.01.004

Eurostat. (2019a). Asylum statistics: Asylum applications (non-EU) in the EU-28 Member States, 20082018. http://ec.europa.eu/eurostat/statistics-explained/index.php?title=Asylum_statistics

Eurostat. (2019b). International migration statistics. https://ec.europa.eu/knowledge4policy/dataset/ ds00026_en

Federal Statistical Office. (2018, April 1). Mikrozensus - Bevölkerung mit Migrationshintergrund [Microcensus - Population with a migration background]. https://www.bpb.de/nachschlagen/zahlenund-fakten/soziale-situation-in-deutschland/150599/migrationshintergrund-iii

Ferrari, R. (2015). Writing narrative style literature reviews. The European Medical Writers Association, 24(4), 230-235. https://doi.org/10.1179/2047480615Z.000000000329

Graf, L., Lassnigg, L., \& Powell, J. J. W. (2012). Austrian corporatism and institutional change in the relationship between apprenticeship training and school-based VET. In M. R. Busemeyer \& C. Trampusch (Eds.), The political economy of collective skill formation (pp. 150-178). Oxford University Press. https://doi.org/10.1093/acprof:oso/9780199599431.003.0006

Granato, M., \& Junggeburth, C. (2017). Geflüchtete in Deutschland - Rechtliche Rahmenbedingungen und soziodemografische Aspekte [Refugees in Germany - Legal Framework and Sociodemo- 
graphic Aspects]. In M. Granato \& F. Neises (Eds.), Geflüchtete und berufliche Bildung [Refugees and vocational education and training] (pp. 12-17). BIBB.

Granato, M., \& Ulrich, J. G. (2013). Die Reformierbarkeit des Zugangs in duale Berufsausbildung im Spannungsfeld institutioneller Widersprüche [The reformability of access to dual vocational training in the context of institutional contradictions]. Schweizerische Zeitschrift für Soziologie, 39(2), 315-339. http://doi.org/10.5169/seals-814998

Hautz, H., \& Thoma, M. (2021). Teacher subjectivation in the quality dispositive: The example of VET in Austria. British Journal of Sociology of Education. https://doi.org/10.1080/01425692.2021.1908117

Heidenreich, M. (2016). Introduction: The double dualization of inequality in Europe. In Heidenreich, M. (Eds.), Exploring Inequality in Europe (pp. 1-21). Edward Elgar Publishing. https://doi. org/10.4337/9781783476664

Herzog-Punzenberger, B., \& Schnell, P. (2012). Die Situation mehrsprachiger Schüler/innen im österreichischen Schulsystem - Problemlagen, Rahmenbedingungen und internationaler Vergleich [The situation of multilingual pupils in the Austrian school system - Problems, general conditions and international comparison]. In B. Herzog-Punzenberger (Ed.), Nationaler Bildungsbericht Österreich 2012, Band 2: Fokussierte Analysen bildungspolitischer Schwerpunktthemen [National education report Austria 2012, Volume 2: Focused analyses of educational policy key issues] (pp. 229-267). Leykam.

Hillmert, S. (2013). Links between immigration and social inequality in education: A comparison among five European countries. Research in Social Stratification and Mobility, 32(1), 7-23. https:// doi.org/10.1016/j.rssm.2013.02.002

Hippach-Schneider, U., \& Huismann, A. (2019). Vocational education and training in Europe: Germany. Cedefop ReferNet VET in Europe reports 2018. https://www.cedefop.europa.eu/en/publications-and-resources/country-reports/vocational-education-and-training-europe-germany-2018

Hosner, R., Vana, I., \& Khun Jush, G. (2017). Integrationsmaßnahmen und Arbeitsmarkterfolg von Flüchtlingen und subsidiär Schutzberechtigen in Österreich [Integration measures and labor market success of refugees and beneficiaries of subsidiary protection in Austria]. Forschungsbericht des FIMAS-Projekts [Research report of the FIMAS-Project]. International Centre for Migration Policy Development. https://www.zsi.at/en/object/project/4109

Huddleston, T., Bilgili, Ö., Joki, A.-L., \& Vankova, Z. (2015). Migrant integration policy index 2015. CIDOB and MPG.

Hunkler, C., \& Tjaden, J. D. (2018). Die Ausbildungsentscheidungen von Migranten im stratifizierten deutschen Bildungssystem: $\mathrm{Zu}$ optimistisch? [Migrants' educational choices in the stratified German education system: Too optimistic?] In E. Schilling (Eds.), Verwaltete Biografen [Managed biographees] (pp. 71-107). Springer Fachmedien.

Hupka-Brunner, S., \& Kriesi, I. (2013). Ausbildungsbedingungen und Ausbildungszufriedenheit in der dualen Grundbildung: Die Rolle von Geschlecht und Migrationshintergrund [Training conditions and training satisfaction in dual basic education: The role of gender and migration background]. In A. Hadjar \& S. Hupka-Brunner (Eds.), Migrationshintergrund, Geschlecht und Bildungserfolg [Migration background, gender and educational attainment] (pp. 242-269). Juventa.

Jackson, M., Jonsson, J. O., \& Rudolphi, F. (2012). Ethnic inequality in choice-driven education systems: A longitudinal study of performance and choice in England and Sweden. Sociology of Education, 85(2), 158-178. https://doi.org/10.1177\%2F0038040711427311 
Jeon, S. (2019). Unlocking the potential of migrants: Cross-country analysis. OECD Publishing. https:// www.oecd-ilibrary.org/education/unlocking-the-potential-of-migrants_045be9b0-en

Kaufmann, S. (2016). Wer Deutsch als Zweitsprache für Geflüchtete unterrichtet, muss dafür aus- und bzw. fortgebildet sein - und gut bezahlt werden. [Those who teach German as a second language to refugees must be trained and well-paid]. http://www.deutsch-am-arbeitsplatz.de/fileadmin/user_ upload/kaufmann_plädoyer.pdf

Kompetenzzentrum Fachkräftesicherung. (2020). Willkommenslotsen [Welcome guides]. https:// www.kofa.de/dossiers/willkommenslotsen

Lessard-Phillips, L., Brinbaum, Y., \& Heath, A. (2014). Academic and vocational tracking in upper secondary education. In A. Heath \& Y. Brinbaum (Eds.), Unequal Attainments: Ethnic Educational Inequalities in Ten Western Countries (pp. 149-167). Oxford University Press. https://doi. org/10.5871/bacad/9780197265741.003.0005

Liebig, T., \& Tronstad, K. R. (2018). Triple disadvantage? A first overview of the integration of refugee women. OECD Social, Employment, and Migration Working Papers, 216, 1-37. https://www.oecdilibrary.org/employment/triple-disadvantage_3f3a9612-en

Mayring, P. (2014). Qualitative content analysis: Theoretical foundation, basic procedures and software solution. Beltz. http://nbn-resolving.de/urn:nbn:de:0168-ssoar-395173

Nielsen-Gravholt, S., \& Jans, D. (2020). Flygtninge i uddannelse [Refugees in training]. Analyse \& Tal. http://www.dsfnet.dk/wp-content/uploads/2020/03/Flygtninge-i-uddannelse_rapport_web.pdf

Nussbaum, M., \& Sen, A. (1993). The quality of life. Clarendon Press. https://doi. org/10.1093/0198287976.001.0001

Patton, M. Q. (1990). Qualitative evaluation and research methods (2nd ed.). SAGE. https://doi. org/10.1002/nur.4770140111

Phillimore, J., \& Goodson, L. (2006). Problem or opportunity? Asylum seekers, refugees, employment and social exclusion in deprived urban areas. Urban Studies, 43(10), 1715-1736. https://doi.org/1 $0.1080 \% 2 \mathrm{~F} 00420980600838606$

Pilz, M. (2018). Typologies to compare different VET systems: Purposes and a new approach. In L. M. Herrera, M. Teräs \& P. Gougoulakis (Eds.), Comparative Issues and Research Concerns in the National Landscapes of Vocational Education and Training (pp. 21-51). Premiss.

Prakopchyk, Y. (2017). Bestehende Möglichkeiten der Flexibilisierung beruflicher Ausbildung [Existing possibilities for making vocational education and training more flexible]. In M. Granato \& F. Neises (Eds.), Geflüchtete und berufliche Bildung. Wissenschaftliche Diskussionspapiere [Refugees and vocational education and training. Scientific discussion papers] (pp. 74-78). BIBB.

Preston, J., \& Green, A. (2008). The role of vocational education and training in enhancing social inclusion and cohesion. In Cedefop (Eds.), Impact of education and training: Fourth report on vocational training research in Europe (pp. 121-193). Cedefop Publications Office.

Rabl, S. M., \& Hautz, H. (2018). Jugendliche mit Fluchterfahrung in der beruflichen Bildung in Österreich - Status Quo und Herausforderungen [Young people with refugee experience in vocational education and training in Austria - Status quo and challenges].bwp@ Österreich Spezial: Wirtschaftspädagogische Forschung und Impulse für die Wirtschaftsdidaktik - Beiträge zum 12. Österreichischen Wirtschaftspädagogikkongress. http://www.bwpat.de/wipaed-at1/rabl_hautz_wipaed-at_2018.pdf

Rambøll. (2018). Evaluering af Integrationsgrunduddannelsen [Evaluation of the basic integration programme] (IGU). Rambøll Management. https://integrationsbarometer.dk/tal-og-analyser/filertal-og-analyser/arkiv/evaluering-af-integrationsgrunduddannelsen 
Schroeder, J., \& Seukwa, L. H. (2017). Access to education in Germany. In A. Korntheuer, P. Pritchard \& D. B. Maehler (Eds.), Structural Context of Refugee Integration in Canada and Germany (pp. 59-64). GESIS - Leibniz Institute for the Social Sciences. https://doi.org/10.21241/ssoar.52101

Seeber, S., Boschke, V., Busse, R., Geiser, P., Michaelis, C., Baethge-Kinsky, V., \& Wiek, M. (2019). Ländermonitor berufliche Bildung 2019. Ein Vergleich der Bundesländer mit vertiefender Analyse zu Passungsproblemen im dualen System [States monitor 2019. A comparison of the federal states with an in-depth analysis of matching problems in the dual system]. Wbv. https://doi. org/10.3278/6004750w

SOS Mitmensch. (2017). Nicht mehr schulpflichtige Asylsuchende: Zugang zu Bildung nicht garantiert. Recherche von SOS Mitmensch für den Zeitraum März bis Juni 2017. [Asylum seekers no longer required to attend school: Access to education not guaranteed. Research by SOS Mitmensch for the period March to June 2017.]. https://www.sosmitmensch.at/dl/NINmJKJKllmJqx4KJK/SOS_Mitmensch_Bildungszugang_Asylsuchende_Juni2017.pdf

Steiner, M. (2009). Early school leaving und Schulversagen im österreichischen Bildungssystem [Early school leaving and school failure in the Austrian education system]. In W. Specht (Ed.), Nationaler Bildungsbericht Österreich 2009, Band 2 Fokussierte Analysen bildungspolitischer Schwerpunktthemen [National education report Austria 2012, Volume 2: Focused analyses of educational policy key issues] (pp. 141-159). Leykam. http://dx.doi.org/10.17888/nbb2009-2

Thomassen, H. (2019). The integration of refugees in Denmark. https://op.europa.eu/en/publicationdetail/-/publication/81826711-c7ac-11e9-9d01-01aa75ed71a1

Tjaden, J. D., \& Scharenberg, K. (2017). Ethnic choice effects at the transition into upper-secondary education in Switzerland. Acta Sociologica, 60(4), 309-324. https://doi. org/10.1177\%2F0001699316679491

Webb, S., Hodge, S., Holford, J., Milana, M., \& Waller, R. (2016). Refugee migration, lifelong education and forms of integration. International Journal of Lifelong Education, 35(3), 213-215. https://doi.or g/10.1080/02601370.2016.1208502

Werner, D. (2018). Engagement von Unternehmen bei der Integration von Flüchtlingen. Herausforderungen und Erfolgsfaktoren [Corporate engagement in the integration of refugees. Challenges and success factors]. Institut der deutschen Wirtschaft. https://kongress2018.bibb.de/wp-content/ uploads/2018/06/forum_V_werner_tag_1_final_dok.pdf

Willems, K., \& Vernimmen, J. (2018). The fundamental human right to education for refugees: Some legal remarks. European Educational Research Journal, 17(2), 219-232. https://doi. org/10.1177\%2F1474904117709386

Winther, E., Jordanoski, G., \& Deutscher, V. K. (2018). Zum Umgang mit fehlenden formalen Qualifikationen [On dealing with a lack of formal qualifications]. Unterrichtswissenschaft, 46(1), 7-20. https://doi.org/10.1007/s42010-018-0012-1

Wissenschaftliche Dienste des Bundestags. (2016). Änderung des Asyl- und Aufenthaltsrechtes seit Januar 2015 mit den Schwerpunkten Asylpaket I und II [Changes to the asylum and residence law since January 2015 with the focus on Asylum Package I and II]. Deutscher Bundestag. https:// www.bundestag.de/resource/blob/424122/05b7770e5d14f459072c61c98ce01672/wd-3-018-16pdf-data.pdf 


\section{Biographical Notes}

Christian Helms Jørgensen is professor of lifelong learning at Roskilde University in Denmark. His research includes comparative studies of vocational education, school-towork transitions, learning in working life and gender \& education.

Hannes Hautz is a senior researcher at the Linz School of Education, Department of Educational Research, Johannes Kepler University Linz (Austria). His research interests focus on teacher professionalism, educational governance, and discourse and power analytical approaches in vocational education and training.

Dr Junmin Li is a senior researcher at the Chair of Economics and Business Education at the University of Cologne in Germany. Her research interests are international comparative research in VET, VET school development, and teaching and learning. 